Etikonomi

Volume 14 (1), April 2015

P-ISSN: 1412-8969; E-ISSN: 2461-0771

Halaman 17 - 34

\title{
PENGARUH KEBIJAKAN PEMISAHAN TERHADAP LABA PADA BANK BNI SYARIAH
}

\author{
Andreyanto Ramdani \\ Universitas Prof. Dr. Hamka \\ andreyantoramdani@gmail.com
}

\begin{abstract}
.
The purpose of this paper is to analyze whether the spin-off policy which is based on law no. 21 in 2008 had an influence on profit of Bank of BNI Syariah period 2007-2015. This study uses multiple regressions using dummy equation to analyze the effect of the spin-off policy to profit at Bank of BNI Syariah. The variable used is a dummy variable spin-off, as well as put some internal factors such Third Party Fund, BOPO. The results shows that the dummy variable spin off and BOPO have an influence on the amount of profit and DPK has no effect on the amount of earnings at Bank of BNI Syariah. These results shown that the spin-off policy BNI Syariah done right.
\end{abstract}

Keywords : spin off; profit; regression; third party fund; BOPO

\begin{abstract}
Abstrak.
Tujuan dari penelitian ini adalah untuk menganalisis apakah kebijakan pemisahan yang didasarkan pada UU. 21 tahun 2008 memiliki pengaruh terhadap jumlah laba BNI Syariah periode 2007-2015. Penelitian ini menggunakan regresi berganda dengan menggunakan persamaan dummy untuk menganalisis pengaruh kebijakan pemisahan terhadap laba. Variabel yang digunakan adalah dummy variabel pemisahan, serta menaruh beberapa faktor internal seperti Dana Pihak Ketiga (DPK) dan BOPO. Hasil penelitian menunjukkan bahwa variabel dummy pemisahan dan BOPO memiliki pengaruh pada jumlah laba dan DPK tidak berpengaruh pada jumlah laba di BNI Syariah. Berdasarkan hasil ini, menunjukkan bahwa kebijakan pemisahan yang dilakukan pada BNI Syariah tepat.
\end{abstract}

Kata kunci : pemisahan; laba; regresi; dana pihak ketiga; BOPO

Diterima: 2 Januari 2015; Direvisi: 10 Februari 2015; Disetujui: 20 Februari 2015 


\section{PENDAHULUAN}

Perbankan dalam kehidupan suatu negara adalah salah satu agen pembangunan. Hal ini dikarenakan adanya fungsi utama dari perbankan itu sendiri sebagai lembaga yang menghimpun dana dari masyarakat dalam bentuk simpanan dan menyalurkan kembali kemasyarakat dalam bentuk kredit atau pembiayaan. Fungsi inilah yang lazim disebut sebagai intermediasi keuangan (Trisadini dan Shomad, 2013).

Perbankan syariah semakin berkembang setelah dikeluarkan UndangUndang Nomor 7 Tahun 1992 tentang perbankan. Pada tahun 1998, UU Perbankan No. 7 Tahun 1992 diamandemen dengan UU No. 10 Tahun 1998. Berbeda dengan UU No. 7 Tahun 1992 yang tidak mengatur secara pasti perbankan syariah, ketentuan-ketentuan mengenai perbankan syariah dalam UU No. 10 Tahun 1998 lebih lengkap dan sangat membantu perkembangan perbankan syariah di Indonesia. Undang-Undang ini juga membolehkan Bank Konvensional untuk menjalankan aktifitasnya berdasarkan prinsip syariah sesuai dengan ketentuan yang ditetapkan Bank Indonesia. Perbankan syariah di Indonesia berkembang cukup pesat, sampai akhir Desember 2014 tercatat telah terdapat 12 Bank Umum Syariah, 22 Unit Usaha Syariah, dan 163 BPRS.

TABEL 1. Perkembangan BUS, UUS dan BPRS di Indonesia

\begin{tabular}{lccccccccc}
\hline Nama & 2006 & 2007 & 2008 & 2009 & 2010 & 2011 & 2012 & 2013 & 2014 \\
\hline BUS & 3 & 3 & 5 & 6 & 11 & 11 & 11 & 11 & 12 \\
UUS & 20 & 25 & 27 & 23 & 23 & 24 & 24 & 23 & 22 \\
BPRS & 105 & 114 & 131 & 139 & 150 & 155 & 158 & 163 & 163 \\
Total & $\mathbf{1 2 8}$ & $\mathbf{1 4 2}$ & $\mathbf{1 6 2}$ & $\mathbf{1 6 8}$ & $\mathbf{1 8 4}$ & $\mathbf{1 9 0}$ & $\mathbf{1 9 3}$ & $\mathbf{1 9 7}$ & $\mathbf{1 9 8}$ \\
\hline
\end{tabular}

Sumber: Bank Indonesia, statistik perbankan syariah 2014

Pada tahun 2008, berdasarkan Undang-Undang No. 21 pasal 68 Tahun 2008 tentang perbankan syariah disahkan yang mengatur tentang pemisahan, yang menjelaskan bahwa bagi Bank Umum Konvensional (BUK) memiliki Unit Usaha Syariah (UUS) yang nilai asetnya paling sedikit 50\% (lima puluh persen) dari nilai total aset bank induknya atau 15 tahun sejak berlakunya undangundang ini, maka bank umum konvensional dimaksud wajib melakukan pemisahan. 
Menurut Peraturan Bank Indonesia (PBI) Nomor 11/10/PBI/2009 tentang Unit Usaha Syariah Bab IX mengenai Pemisahan Unit Usaha Syariah pada Pasal 41 dijelaskan bahwa pemisahan UUS dari BUK dapat dilakukan dengan cara mendirikan BUS baru atau mengalihkan hak dan kewajiban UUS kepada BUS yang telah ada. Pemisahan UUS dengan cara pengalihan kepada BUS yang telah ada hanya dapat dilakukan kepada BUS yang memiliki hubungan kepemilikan dengan BUK yang memiliki UUS.

Beeson dan Hyden (2002) menyatakan bahwa perusahaan yang melaksanakan spin-off memisahkan unit atau divisi bisnisnya menjadi perusahaan anak. Perusahaan tersebut kemudian membagikan saham perusahaan anak kepada pemegang sahamnya secara pro-rata, lazimnya melalui pernyataan pembagian dividen khusus. Beeson dan Hyden lebih lanjut menjelaskan bahwa spin-off dapat diikuti dengan penawaran saham kepada publik untuk sejumlah kecil (minority stake) saham perusahaan anak.

Rizqullah (2013) mengartikan spin-off sebagai upaya pemisahan atau pengalihan sebagian aset perusahaan yang kemudian menjadi perusahaan independen, sementara perusahaan yang melakukan pemisahan atau pengalihan masih tetap beroperasi dan menjadi perusahaan induk dari perusahaan independen tersebut yang disebut juga perusahaan anak. Perusahaan induk memiliki kontrol terhadap perusahaan anak dan saham keduanya dimiliki oleh pemegang saham perusahaan induk.

Menurut Elfring dan Foss (1997) terdapat dua tipe pemisahan, yaitu: pertama, dari sisi perusahaan induknya, dimana perusahaan induk karena suatu alasan tertentu tidak mampu atau tidak dapat mengeksploitasi kesempatan yang didapat. Tipe kedua ialah terkait unit organisasi sebagai individu, pada tipe yang kedua ini merupakan tipe yang paling banyak dilakukan, dimana perusahaan anak tidak sama dengan perusahaan induknya. Dan tipe kedua inilah yang terdapat pada pemisahan unit usaha syariah pada bank konvensional di Indonesia. 
Alasan yang melatarbelakangi munculnya ide pemisahan (spin-off) antara lain, sebagai berikut (Nasuha, 2013): Pertama, restrukturisasi perusahaan yang diprakarsai oleh perusahaan induk. Mereka sering menjalankan sesuai konsekuensi restrukturisasi. Perusahaan induk memberi dukungan dan dorongan semangat kepada pengusaha baru. Kedua, dalam rangka pendirian usaha baru yang dijalankan oleh satu atau beberapa orang, dengan memanfaatkan pengalaman yang diperoleh dari pengalaman perusahaan induk.

Pemisahan merupakan pemisahan unit bisnis, divisi atau perusahaan anak dari perusahaan induk sehingga tercipta entitas bisnis yang baru dan independen (Moin, 2003). Dalam hal ini sebelum tahun 2008 hanya terdapat 3 bank umum syariah dan setelah dikeluarkan undang-undang No. 21 tahun 2008 jumlah bank umum syariah telah bertambah menjadi 12 bank. Pembentukan BUS baru ini dapat melalui pemisahan murni maupun pemisahan dengan akuisisi dan konversi. Adapun pertumbuhan aset, Dana Pihak Ketiga (DPK), dan pembiayaan BNI Syariah sebagaimana pada Tabel 2.

Tabel 2. Pertumbuhan Aset, DPK dan Pembiayaan BNI Syariah

\begin{tabular}{lccc}
\hline \multicolumn{1}{c}{ Tahun } & $\mathbf{2 0 1 2}$ & $\mathbf{2 0 1 3}$ & $\mathbf{2 0 1 4}$ \\
\hline Aset (Juta Rp) & $10,645,313$ & $14,708,504$ & $19,492,112$ \\
Pertumbuhan (\%) & 25.72 & 38.16 & 32.54 \\
Dana Pihak Ketiga (juta Rp) & $8,980,035$ & $11,488,209$ & $16,246,405$ \\
Pertumbuhan (\%) & 42.91 & 27.93 & 41.41 \\
Pembiayaan (juta Rp) & $7,631,994$ & $11,242,241$ & $14,939,349$ \\
Pertumbuhan (\%) & 43.72 & 47.30 & 32.88 \\
\hline
\end{tabular}

Sumber : BNI Syariah

Kiswanto (2012) melakukan kajian terhadap roadmap pemisahan yang disusun oleh UUS. Berdasarkan kajian yang dilakukan dapat disimpulkan bahwa rencana pemisahan yang diajukan oleh masing-masing bank tidak selalu dapat digunakan sebagai acuan. Hanya beberapa bank saja yang rencana pemisahannya cukup beralasan untuk dapat direalisasikan. Beberapa bank lain terlihat sangat optimis dalam merencanakan waktu pemisahannya, namun jika 
melihat potensinya sangat sulit untuk dilaksanakan, dan sebaliknya terdapat juga beberapa bank yang sangat konversatif dalam merencanakan pemisahannya hingga mendekati batas akhir padahal kemampuan permodalannya sudah cukup memadai. Kiswanto (2012) mengelompokkan masing-masing bank tersebut berdasarkan potensi permodalanya, yaitu: (i) Modal induk di atas Rp2 trilyun dan modal UUS di atas Rp500 milyar, sehingga secara ketentuan telah memenuhi persyaratan permodalan dan diharapkan dapat segera melakukan pemisahan UUS. Bank-bank yang masuk dalam kelompok ini adalah BTN, Bank Permata, CIMB Niaga, dan Bank Danamon. (ii) Modal induk di atas Rp2 trilyun namun modal UUS masih dibawah Rp500 milyar, sehingga masih memerlukan upaya dan waktu yang lebih lama untuk menambah modal UUS nya agar mencapai persyaratan minimal sebesar Rp500 milyar. Terdapat 5 bank yang memenuhi kriteria tersebut yaitu: BII, BTPN, OCBC-NISP, HSBC, Bank Jatim. (iii) Modal induk masih di bawah Rp2 trilyun namun lebih dari Rp1 trilyun, sehingga memerlukan upaya yang lebih besar karena harus menambah modal induknya agar mencapai Rp2 trilyun, maupun untuk menambah modal UUS-nya. Bank yang masuk dalam kategori ini ialah: BPD Jateng, BPD Banda Aceh, BPD Sumut, Bank DKI, Bank Sinarmas, BPD Riau, BPD Sumsel \& Babel, BPD Sumbar, dan BPD Jambi. (iv) Modal induk dibawah Rp1 trilyun, sehingga sangat sulit untuk memenuhi kewajiban melakukan pemisahan. Bank yang masuk dalam kategori ini ialah BPD Kaltim, BPD Kalsel, BPD Kalbar, BPD Sulsel, BPD NTB dan BPD DIY.

Menurut Kiswanto (2012) terdapat beberapa strategi yang dapat dilakukan terkait dengan hal diatas. Pertama, melakukan pemisahan murni UUS menjadi BUS; Kedua, bergabung bersama beberapa bank lain; Ketiga, melakukan akuisisi terhadap bank konvensional, kemudian melakukan konversi atas bank yang telah diakusisi menjadi bank syariah; Keempat, melakukan konversi bank induk konvensionalnya menjadi bank syariah.

Tabel 2 menunjukkan bahwa dalam tiga tahun belakangan ini dimana tahun 2012 tingkat pertumbuhan aset mengalami fluktuasi sebesar $25.72 \%$ pada tahun 2012-2013 mengalami peningkatan sebesar 38.16\% dan pada tahun 
2013-2014 pertumbuhan aset menglami penurunan sebesar 32.54\%, dan dari sisi dana pihak ketiga (DPK) mengalami fluktuasi sama halnya dengan aset yaitu pada tahun 2012 pertumbuhan DPK sebesar 42.91\% lalu pada tahun 2012-2013 pertumbuhan DPK mengalami penurunan sebesar 27.93\% pada 2013-2014 pertumbuhan DPK meningkat kembali sebesar 41.41\%. sedangkan pada sisi pembiayaan pertumbuhan mengalami fluktuasi sama halnya dengan aset dan DPK yaitu pada tahun 2012 sebesar 43.72\% dan meningkat sebesar 47.30\% pada tahun2012-2013, lalu pada tahun 2013-2014 pertumbuhan pembiayaan mengalami penurunan sebesar $32.88 \%$. berdasarkan data di atas, telah terjadi inkonsistensi pada kinerja keuangan Bank BNI Syariah pada tahun 2011 sampai 2014. Seharusnya dengan melakukan pemisahan bank BNI Syariah mampu meningkatkan pertumbuhan pada kinerja keuangannya secara utuh.

Masalah yang terjadi pada Bank BNI Syariah jika dilihat pada data pertumbuhan aset, DPK dan pembiayaan pada periode 2012 sampai 2014 mengalami fluktuasi atau tidak stabil dari tahun ke tahun. Seharusnya dengan merujuk pada Undang-Undang No. 21 Tahun 2008 tentang pemisahan bank yang melakukan pemisahan diharuskan dapat menjaga kinerja keuangannya untuk terus meningkatkan kinerjanya dari tahun ke tahun.

Tabel 3 menjelaskan perkembangan laba (rugi) dari BUS hasil pemisahan. Berdasarkan data tersebut terlihat bahwa BNI Syariah mengalami kerugian ketika satu tahun sebelum pemisahan ini dilakukan, dimana porsi biaya operasional terbesar pada periode tersebut ialah dialokasikan pada penyisihan penghapusan aktiva produktif yaitu hampir sebesar 70\%. BRI Syariah mengalami kerugian pada satu tahun sebelum pemisahan dan ketika tahun pemisahan tersebut dilakukan. Setelah itu BRI Syariah selalu membukukan laba operasional, meskipun pada tahun 2014 terjadi penurunan laba yang signifikan jika dibandingkan dengan dua tahun sebelumnya. BJB Syariah relatif lebih stabil pada proses pemisahan ini terkait dengan laba operasional yang diperoleh baik sebelum ataupun sesudah pemisahan, meskipun pada Desember 2012 sempat mengalami rugi operasional. Bank 
Syariah Bukopin menunjukkan laba yang fluktuatif, namun Bank Syariah Bukopin masih memiliki akumulatif rugi akhir tahun 2014 sebesar \pm 149 milyar.

Tabel 3. Perkembangan Laba/Rugi Per Desember 2014 (dalam jutaan Rp)

\begin{tabular}{crrrr}
\hline Periode & BNI Syariah & BRI Syariah & BJB Syariah & Bukopin Syariah \\
\hline 2005 & 6,819 & 1,961 & 10,989 & 2,228 \\
2006 & 15,217 & 17,320 & 21,689 & $-2,242$ \\
2007 & 19,237 & $-4,608$ & 21,272 & 8,082 \\
2008 & 34,439 & $-\mathbf{3 5 , 6 5 7}$ & 23,255 & $\mathbf{1 6 , 6 3 2}$ \\
2009 & $-186,509$ & 16,216 & 33,182 & 832 \\
2010 & $\mathbf{3 6 , 5 1 2}$ & 10,954 & $\mathbf{5 , 3 9 3}$ & 10,234 \\
2011 & 66,354 & 11,654 & 18,395 & 12,209 \\
2012 & 101,892 & 101,888 & $-18,180$ & 17,298 \\
2013 & 186,218 & 129,564 & 28,316 & 27,245 \\
2014 & 163,251 & 6,577 & 22,744 & 12,770 \\
\hline
\end{tabular}

Sumber: Laporan Publikasi Bank

Angka yang dicetak tebal menunjukkan tahun pemisahan BUS bersangkutan

\section{METODE}

Ruang lingkup penelitian pada penelitian ini ialah penelitian kausal yang bertujuan untuk menganalisis kemungkinan hubungan sebab dan akibat antara variabel independen dengan variabel dependen. Dalam penelitian ini menganalisis pengaruh kebijakan pemisahan terhadap jumlah laba. Objek penelitian ini diambil dari laporan keuangan Bank Negara Indonesia syariah pada periode 2007-2015. Maka analisis regresi persamaan matematika yang digunakan:

$$
\mathrm{Y}_{\mathrm{t}}=\alpha+\beta_{1} \mathrm{D} \_ \text {spin off }_{t}+\beta_{2} \mathrm{DPK}_{\mathrm{t}}+\beta_{3} \mathrm{BOPO}_{\mathrm{t}}+\mathrm{u}_{\mathrm{t}}
$$

Keterangan:

$\mathrm{Y}_{\mathrm{t}} \quad=$ Jumlah laba

D_spinoff $_{\mathrm{t}}=$ variabel boneka pemisahan

Dimana: $\mathrm{D}=0$ : sebelum pisah; $\mathrm{D}=1$ : sesudah pisah

DPK $_{\mathrm{t}} \quad=$ Dana pihak ketiga

$\mathrm{BOPO}_{\mathrm{t}}=$ Biaya operasional dan Pendapatan operasional

$\mathrm{u}_{\mathrm{t}} \quad=$ kesalahan random 
Setelah pengolahan analisis regresi , untuk melihat apakah model yang baik atau buruk kita harus mengetahui persamaan matematika yang bagus ini dari model dipakai. Untuk melihat kebaikan sesuai model, kita harus melihat uji $t$, uji $F$ dan koefisien determinasi $\left(R^{2}\right)$. Uji statistik $t$ pada dasarnya menunjukan seberapa jauh pengaruh variabel penjelas secara individual dalam menerangkan variasi variabel terikat. Membandingkan nilai statistik $\mathrm{t}$ dengan titik kritis menurut tabel apabila nilai statistik $t$ hasil hitung lebih tinggi dibanding nilai t tabel, kita menerima hipotesis alternatif, yang menyatakan bahwa suatu variabel independen secara individual mempengaruhi variabel dependen.

Uji statistik F pada dasarnya kriteria pengambilan keputusan dilakukan dengan tingkat signifikansi 5\%. $\mathrm{H}_{\mathrm{a}}$ akan diterima jika tingkat signifikansi $<5 \%$ (kurang dari 0,05) dan $\mathrm{H}_{\mathrm{a}}$ ditolak apabila tingkat signifikansi > 5\%. Apabila $\mathrm{t}$ hitung $>\mathrm{t}$ tabel maka $\mathrm{H}_{0}$ ditolak dan ha diterima, artinya variabel independen secara parsial mempunyai pengaruh yang signifikan terhadap variabel dependen. Apabila t hitung $<\mathrm{t}$ tabel maka $\mathrm{H}_{0}$ diterima dan $\mathrm{H}_{\mathrm{a}}$ ditolak, artinya variabel independen secara simultan tidak mempunyai pengaruh yang signifikan terhadap variabel dependen.

Koefisien determinasi $\left(\mathrm{R}^{2}\right)$ pada intinya mengukur seberapa jauh kemampuan model dalam menerangkan variasi variabel dependen. Nilai koefisien determinasi adalah antara 0 (nol) dan 1 (satu). Nilai $\mathrm{R}^{2}$ yang kecil berarti kemampuan variabel-variabel independen memberikan hampir semua informasi yang dibutuhkan untuk memprediksi variasi variabel dependen. nilai adjusted $\mathrm{R}^{2}$ juga berkisar antara 0 (nol) dan 1 (satu). Apabila mendekati nilai 1 (satu) berarti semakin kuat kemampuan variabel independen dalam menjelaskan variabel dependennya.

\section{PEMBAHASAN}

Menurut pengolahan data berdasarkan uji statistik t, uji $\mathrm{F}$ dan uji $\mathrm{R}^{2}$ pada bank BNI Syariah periode 2007-2015, mendapatkan hasil seperti pada Tabel 4. Berdasarkan Tabel 4, terlihat bahwa yang mempengaruhi jumlah laba operasional pada Bank BNI Syariah ialah variabel pemisahan (spin-off) dan 
variabel BOPO. Variabel pemisahan memiliki pengaruh yang positif terhadap peningkatan jumlah laba operasional di Bank BNI Syariah, sehingga pemisahan unit usaha syariah menjadi bank umum syariah mampu meningkatkan laba operasional. Selain itu variabel BOPO yang negatif menunjukkan bahwa semakin efisien Bank BNI syariah maka akan semakin meningkatkan laba operasional. Variabel dana pihak ketiga tidak memiliki pengaruh terhadap jumlah laba operasional yang diperoleh oleh Bank BNI Syariah, hal ini menunjukkan bahwa penentuan jumlah laba tidak tergantung pada jumlah dana pihak ketiga yang mampu dihimpun.

\section{Tabel 4. Hasil Estimasi Regresi}

\begin{tabular}{|c|c|c|c|c|c|c|}
\hline \multirow[b]{2}{*}{ Mod } & & \multicolumn{2}{|c|}{$\begin{array}{l}\text { Unstandardized } \\
\text { Coefficients }\end{array}$} & \multirow{2}{*}{$\begin{array}{c}\text { Standardized } \\
\text { Coefficients } \\
\text { Beta } \\
\end{array}$} & \multirow[b]{2}{*}{$\mathrm{t}$} & \multirow[b]{2}{*}{ Sig. } \\
\hline & & $\mathrm{B}$ & Std. Error & & & \\
\hline \multirow[t]{4}{*}{1} & (Constant) & 17.508 & 29.481 & & .594 & .557 \\
\hline & Spin_off & 8.545 & 2.956 & .583 & 2.890 & .007 \\
\hline & DPK & 1.123 & 2.056 & .114 & .546 & .589 \\
\hline & BOPO & -3.582 & .562 & -.815 & -6.369 & .000 \\
\hline
\end{tabular}

Jika melihat pada hasil uji F menunjukkan hasil yang signifikan, hal ini menandakan bahwa secara simultan seluruh variabel bebas, yaitu variabel pemisahan, dana pihak ketiga, dan BOPO berpengaruh terhadap laba operasional pada bank BNI Syariah. Kemudian nilai adjusted $\mathrm{R}^{2}$ sebesar 0.637 menunjukkan bahwa $63.7 \%$ model ini mampu menjelaskan variabel yang mempengaruhi laba operasional, sedangkan 36.3\% dijelaskan oleh variabel lain di luar model yang ada. Hasil empiris di atas menunjukkan bahwa terdapat perbedaan jumlah laba operasional pada Bank BNI Syariah antara sebelum dan sesudah kebijakan pemisahan (spin-off) dilakukan. Hal ini menunjukkan bahwa kebijakan tersebut memiliki peran penting dalam menunjang keuntungan bank, dilihat dari jumlah laba sebelum bank melakukan pemisahan yaitu pada tahun 2007- 2010 triwulan awal total laba sebesar 72.73\% dan sesudah pemisahan jumlah laba meningkat menjadi $191.82 \%$ hingga triwulan pertama di tahun 2015. Hasil pengujian menunjukkan bahwa pengaruh kebijakan pemisahan 
terhadap jumlah laba sesuai dengan teori yang dikembangkan. Penelitian ini menunjukan bahwa hasil kebijakan spin off berpengaruh positif terhadap jumlah laba.

Instruksi langsung bank-bank syariah yang ingin melakukan pemisahan karena merespon atas pertumbuhan bisnis bank syariah, dan kesadaran konsumen yang kian meningkat. Maka muncul regulasi untuk industri perbankan syariah dengan dikeluarkan Undang-Undang No. 21. Pasal 68 Tahun 2008 tentang perbankan syariah disahkan yang mengatur pemisahan, menjelaskan pertama dalam hal Bank Umum Konvensional memiliki Unit Usaha Syariah yang nilai asetnya paling sedikit 50\% dari nilai total aset bank induknya atau 15 tahun sejak berlakunya Undang-Undang ini maka Bank Umum Konvensional dimaksud wajib melakukan pemisahan. Kedua UUS tersebut menjadi BUS. Ketentuan lebih lanjut mengenai pemisahan dan sanksi bagi BUK yang tidak melakukan pemisahan sebagaimana diatur pada ayat 1 diatur dengan Peraturan Bank Indonesia. dan Undang-Undang No. 19 Tahun 2008 mengenai Surat Berharga Syariah Negara (SBSN) yang diterbitkan untuk memperkuat dan meningkatkan peran sistem keuangan syariah keuangan berbasis syariah di dalam negeri, mendorong pertumbuhan pasar keuangaan syariah di Indonesia. Serta muncul Peraturan Bank Indonesia (PBI) No. 11/10/PBI/2009 tentang Unit Usaha Syariah menjelaskan: pertama modal disetor pendirian BUS hasil akuisisi dan konversi minimal 100 Miliar dan modal itu harus dipelihara. Kedua, modal disetor hasil pemisahan murni 500 Miliar dan wajib ditingkatkan secara bertahap selama 10 tahun setelah ijin diberikan. Hal tersebut merupakan langkah strategis bagi perkembangan industri perbankan syariah di masa depan yang akan melakukan pemisahan. Di sisi lain, pertumbuhan industri dalam lima tahun terakhir perbankan syariah menunjukan angka pertumbuhan yang sangat signifikan jika dibandingkan dengan potensi pasar yang ada maka peluang pengembangan perbankan syariah masih terbuka luas.

Hal yang membuat laba BNI Syariah stabil karena bank tersebut mendirikan Unit Usaha Syariah (UUS) sejak tahun 2000 dan baru berubah menjadi BUS di tahun 2010, hal itulah yang membuat laba BNI Syariah stabil apa 
lagi persiapan BNI Syariah melakukan pemisahan menjadi BUS sudah cukup lama yaitu dari tahun 2008, dari sisi teknologi juga BNI syariah mempunyai SDM yang mempenghuni hingga mampu menaikkan jumlah laba. Kebijakan pemisahan berpengaruh dengan jumlah laba dikarenakan setiap bank syariah yang melakukan pemisahan pasti secara langsung dapat meningkatkan jumlah laba dan mengurangi biaya-biaya operasional. Jadi bank yang sudah melakukan pemisahan bisa lebih leluasa berkembang dalam produk dan melebarkan sayap dalam pangsa pasar yang lebih luas. Hal lain yang mampu menjadikan Bank BNI Syariah relatif stabil bahkan semakin meningkat ialah strategi bank induk konvensional (Bank BNI) yang masih memperbolehkan Bank BNI Syariah untuk menggunakan fasilitas teknologi informasi yang dimiliki induknya, sehingga hal ini menjadikan biaya operasional pada Bank BNI Syariah tidak terlalu meningkat drastis.

Hasil penelitian ini sama dengan Hamid (2015) yang menyatakan bahwa variabel dummy pemisahan berpengaruh terhadap tingkat profitabilitas. Hamid (2015) melakukan penelitian terkait dengan pengaruh kebijakan pemisahan terhadap industri perbankan syariah dengan ruang lingkup penelitian semua bank yang sudah BUS, metode menggunakan kuantitatif reggresi dummy, varibel yang digunakan ROA, NPF, spin off, BOPO dan margin satu bulan deposito. Hasil yang didapatkan bahwa variabel yang berpengaruh terhadap ROA hanyalah variabel pemisahan, tingkat pembiayaan bermasalah (NPF) dan tingkat efisiensi operasional (BOPO).

Hasil yang dilakukan oleh peneliti bahwa pengaruh DPK terhadap jumlah laba pada BNI Syariah tidak memiliki pengaruh terhadap jumlah laba. Hal itu dapat terjadi bahwa pada dasarnya DPK tidak memiliki pengaruh signifikan terhadap jumlah laba yang diuji oleh peneliti. Hal ini sesuai dengan pendapat Kasmir (2008) yang mengatakan bahwa sesuai dengan fungsi bank sebagai lembaga keuangan di mana kegiatan sehari-harinya adalah bergerak di bidang keuangan, maka sumber-sumber dana juga tidak terlepas dari bidang keuangan. Untuk menopang kegiatan bank sebagai penjual uang (memberikan 
pinjaman), bank harus lebih dulu membeli uang (menghimpun dana) sehingga dari selisih bunga tersebutlah bank memperoleh keuntungan

Hal ini menunjukan bahwa semakin besar DPK yang dimiliki oleh bank, belum tentu mencerminkan laba yang besar, disebabkan karena ketidakseimbangan antara jumlah sumber dana yang masuk dengan jumlah pembiayaan yang disalurkan kepada masyarakat. Semakin tinggi DPK yang terkumpul di bank namun tidak diimbangi dengan penyaluran pembiayaan maka kemungkinan bank mengalami kerugian atau penurunan laba karena pendapatan margin dari pembiayaan kepada kreditur tidak mencukupi untuk menutupi biaya pendapatan margin yang harus dibayarkan kepada deposan, hal tersebut dapat terjadi karena alokasi dana yang terhimpun bank belum mampu dioptimalkan untuk menghasilkan laba bagi bank yang mengakibatkan terjadinya pengendapatan dana. Hal ini dapat dilihat dari tingkat pertumbuhan yang kurang maksimal pada pembiayaan, dilihat dari akhir tahun 2014 yang hanya 32\% dibandingkan dari tahun sebelumnya 2013 sebesar 47\%.

Kemudian pengaruh BOPO terhadap jumlah Laba, hasil yang didapat menunjukkan pengaruh BOPO terhadap jumlah laba pada BNI Syariah. Hasil pengujian BOPO terhadap jumlah Laba pada dasarnya ketika bank baru melakukan pemisahan maka bank tersebut akan banyak mengeluarkan biaya operasional dikarenakan segala sesuatu kegiatan bank dimulai dari nol seperti pembukaan kantor dan alat operasional lainnya. Dengan demikian bisa dikatakan ketika biaya meningkat maka jumlah laba yang didapatkan juga sedikit. selain itu bank juga belum memiliki kemapanan secara mandiri sehingga bank tersebut memerlukan waktu untuk beradaptasi. Jadi dapat ditarik kesimpulan bahwa BOPO yang tinggi dapat mempengaruhi jumlah laba setelah melakukan pemisahan. Sama halnya dalam surat edaran BI No. 3/30 DPNP tanggal 14 Desember 2001, BOPO diukur dari perbandingan antara biaya operasional terhadap pendapatan operasional. Semakin kecil rasio BOPO berarti semakin efisien biaya operasional yang dikeluarkan oleh bank yang bersangkutan, dan setiap peningkatan pendapatan operasional akan berakibat 
pada berkurangnya laba sebelum pajak yang pada akhirnya akan menurunkan laba atau profitabilitas yang bersangkutan.

Penelitian terkait dengan pemisahan masih belum terlalu banyak. Nasuha (2012) melakukan penelitian terkait perbedaan kinerja unit usaha syariah yang memutuskan untuk pisah (BNI Syariah, BRI Syariah, BJB Syariah, BSB, dan Bank Victoria Syariah) satu tahun sebelum dan satu tahun setelah melakukan pemisahan. Hasil yang didapatkan menunjukan bahwa terdapat perbedaan kinerja antara sebelum dan sesudah pemisahan terjadi pada 3 variabel, yaitu Aset, Pembiayaan, dan Dana Pihak Ketiga (DPK). Sedangkan pada variabel CAR, FDR, ROA, dan ROE tidak menunjukkan perbedaan kinerja antara 1 tahun sebelum dan 1 tahun sesudah pemisahan.

Marlina (2015), melakukan penelitian analisis kinerja keuangan pada Bank Umum Syariah yang terbentuk melalui spin off, metode yang dipakai analisis pattern matching, dengan hasil spin off terbukti bermanfaat menaikan kinerja perusahaan. Penelitian ini menggunakan data keuangan BNI Syariah dan UUS BNI serta data hasil wawancara dengan kepala cabang BNI Syariah Yogyakarta. Alat ukur yang digunakan dalam penelitian ini meliputi aset, laba bersih, total pendanaan, pembiayaan, CAR, ROA, ROE, FDR, kinerja nonkeuangan, BOPO, NPF dan harga saham saat pengumuman spin-off. Data tersebut dianalisis dengan melihat tren kinerja BNI Syariah dan UUS BNI dan pattern matcing. Hasil dari penelitian ini menunjukkan bahwa spin-off terbukti bermanfaat meningkatkan kinerja keuangan BNI Syariah melalui peningkatan fokus, otonomi, dan independensi serta peningkatan efisiensi dan kinerja operasional namun tidak terbukti meningkatkan kekayaan pemegang saham.

Morgan P Miles, dkk (1992) melakukan penelitian mengenai perbedaan tingkat orientasi pemasaran antara perusahaan spin-off dan organisasi non-spinoff. Hasil penelitian yang dilakukan mengindikasikan bahwa tidak terdapat perbedaan tingkat orientasi kewirausahaan (entrepreneurial) antara perusahaan spin-off dan organisasi non-spin-off. Temuan ini gagal untuk membuktikan berbagai kajian yang menyarankan bahwa pemisahan mungkin 
dapat mengutilisasi baik orientasi pemasaran dan/atau kewirausahaan sebagai suatu respon strategis pada lingkungan yang dinamis. Miles dan Rosenfeld (1983) melakukan kajian dampak pengumuman pemisahan pada kesejahteraan dari para pemegang saham. Hasil yang didapat menunjukkan bahwa pengumuman pemisahan memiliki pengaruh yang positif terhadap harga saham. Pemisahan yang besar memiliki pengaruh positif yang lebih kuat terhadap kesejahteraan pemegang saham secara relatif dibandingkan dengan pemisahan yang kecil.

Simbolon (2012) melakukuan penelitian berjudul, analisa perbandingan kinerja keuangan perusahaan sebelum dan sesudah divestasi dan spin off, metode yang dipakai kuantitatif dengan pendekatan purposive sampling, hasilnya pengujian selama satu tahun dan sesudah menunjukan tidak ada perbedaan yang signifikan. Wicaksono (2014) melakukan penelitian efesiensi teknis perbankan Indonesia pada bank yang merger-akuisisi dan pemisahan, menggunakan metode kuantitatif analisis DEA. Dengan hasil perbankan yang terbentuk dari hasil pemisahan memiliki efisiensi yang lebih baik secara keseluruhan dibandingkan dengan bank yang terbentuk dari merger.

Al Arif (2015) melakukan penelitian terkait dengan pengaruh kebijakan pemisahan terhadap pertumbuhan pembiayaan pada industri perbankan syariah di Indonesia, teknik analisis yang dipergunakan ialah regresi panel dengan model efek tetap. Hasil yang didapat menunjukkan bahwa kebijakan pemisahan tidak berpengaruh terhadap jumlah pembiayaan pada bank umum syariah hasil pemisahan.

Al Arif (2015) melakukan penelitian pula untuk melihat keterkaitan antara kebijakan pemisahan terhadap tingkat efisiensi pada industri perbankan syariah di Indonesia. Teknik analisis yang dipergunakan regresi berganda dengan menggunakan variabel BOPO sebagai variabel terikat yang mengukur tingkat efisiensi operasional, dan beberapa variabel bebas seperti variabel dummy pemisahan, dana pihak ketiga, pembiayaan, aset, tingkat pembiayaan bermasalah, tingkat marjin deposito satu bulan, dan tingkat profitabilitas. Hasil yang didapat menunjukkan bahwa terdapat pengaruh antara kebijakan 
pemisahan terhadap tingkat efisiensi operasional pada bank umum syariah, dimana kebijakan pemisahan justru menurunkan tingkat efisiensi operasional pada industri perbankan syariah di Indonesia. Hal ini menunjukkan bahwa setelah kebijakan pemisahan dilakukan justru mengakibatkan industri perbankan syariah menjadi kurang efisien dibandingkan sebelum kebijakan pemisahan tersebut dilakukan.

Berdasarkan berbagai hasil yang didapat menunjukkan bahwa kebijakan pemisahan unit usaha syariah menjadi Bank Umum Syariah (BUS) merupakan salah satu strategi bisnis yang dapat diambil untuk mengembangkan industri perbankan syariah. Namun kebijakan pemisahan ini bukan merupakan tujuan akhir dari pengembangan industri perbankan syariah, banyak hal yang perlu disiapkan terkait dengan pemisahan unit usaha syariah menjadi bank umum syariah ini.

Menurut Tubke (2004) terdapat beberapa faktor yang memengaruhi dalam proses pemisahan (spin-off). Pertama, faktor yang terkait dengan aktivitas bisnis, dalam faktor yang pertama ini terkait dengan ukuran perusahaan dan perbedaan sektor bisnis antara perusahaan induk dengan perusahaan anaknya. Apabila faktor pertama ini dikaitkan dengan unit usaha syariah dapat diposisikan sebagai perusahaan anak dan bank konvensional sebagai perusahaan induk. Kedua, faktor yang terkait dengan organisasi dan pengelolaan perusahaan. Ketiga, faktor yang terkait dengan hubungan dan dukungan. Terdapat tiga pola hubungan yang mungkin dapat tercipta antara perusahaan induk dengan perusahaan anak yang melakukan pemisahan, yaitu hubungan pasar (market-relatedness), hubungan produk (product relatedness), dan hubungan teknologi (technology-relatedness). Keempat, faktor transfer atau pengalihan berupa transfer pengalaman dari perusahaan induk kepada perusahaan anaknya. Kelima, faktor terkait dengan motivasi. Keenam, faktor terkait dengan lingkungan bisnis baik berupa karakteristik lingkungan bisnis regional maupun kerangka legal.

Siswantoro (2014) dalam artikelnya yang menganalisis kinerja dan strategi bank syariah setelah pemisahan dan muncul sebagai suatu bank umum 
yang terpisah dari bank induknya. Hasil analisis yang didapat menunjukkan bahwa bank umum syariah hasil pemisahan seharusnya dapat mengoptimalkan beberapa sumber daya pendanaan seperti suntikan permodalan dan peningkatan deposit investasi sementara.

\section{SIMPULAN}

Hasil analisis data menunjukan bahwa sebelum dan sesudah kebijakan pemisahan menggunakan variabel dummy memiliki pengaruh yang positif signifikan terhadap jumlah laba pada BNI Syariah. BOPO memiliki pengaruh signifikan terhadap jumlah laba, tetapi pada DPK tidak berpengaruh terhadap jumlah laba. Jadi, dapat disimpulkan bahwa kebijakan pemisahan memiliki pengaruh signifikan pada jumlah laba di BNI Syariah pada tahun 2007-2015. Hasil yang diperoleh dari penelitian ini menunjukan bahwa kebijakan pemisahan yang dilakukan oleh BNI Syariah tepat. Namun yang harus diingat ialah suatu bank induk konvensional harus memiliki persiapan yang matang ketika akan memutuskan untuk memisahkan unit usaha syariahnya.

\section{PUSTAKA ACUAN}

Al Arif, M. N.R. 2015. The Effect of spin off policy on Financing Growth in Indonesia Islamic Banking Industry. Journal Al-Ulum, Vol. 15, No.1, pp. 173-184

Al Arif, M.N.R. 2015. Keterkaitan Kebijakan Pemisahan Terhadap Tingkat Efisiensi pada Industri Perbankan Syariah di Indonesia. Jurnal Keuangan dan Perbankan. Vol. 19, No. 2, hlm. 295-304.

Hamid, A. 2015. The Impact of Spin off Policy to the Profitability on Indonesia Islamic Banking Industry. Al-Iqtishad: Jurnal Ilmu Ekonomi Syariah (Journal of Islamic Economics). Vol 7, No. 1, pp. 117126.

IFSB (Islamic Financial Services Board). 2009. Guiding Principles on Shari'ah Governance Systems for Institutions Offering Islamic Financial Services. Kasmir. 2008. Bank dan Lembaga Keuangan Lainnya. Jakarta: RajaGrafindo Persada. 
Kiswono, Bambang. 2012. Spin Off Unit Usaha Syariah (UUS), Kendala dan Strategi Penyelesaiannya. (Makalah Tidak Dipublikasikan). Jakarta: Bank Indonesia

Lewis, Mervin K. dan Latifa M. Algaud. 2001. Perbankan Syariah Prinsip Praktek Prospek. Jakarta: PT. Serambi Ilmu Semesta.

Maksum, Azhar. 2005. Tinjauan atas Good Corporate Governance di Indonesia. Medan: Gelanggang Mahasiswa, Kampus USU.

Marlina, Y. 2015. Analisis Kinerja Keuangan Pada BUS yang Terbentuk Melalui Spin off. (Skripsi Tidak Dipublikasikan). Yogyakarta: Universitas Gadjah Mada.

Moin, A. 2003. Merger, Akuisisi \& Divestasi. Yogyakarta: PT. Ekonesia.

Nasuha, A. 2012. Dampak Kebijakan Spin-off Terhadap Kinerja Bank Syariah. AlIqtishad: Jurnal Ilmu Ekonomi Syariah (Journal of Islamic Economics). Vol. 4, No. 2. hlm. 241-258.

Priyatno, Duwi. 2005. Buku Saku Analisis Data SPSS

Rizqullah. 2013. Pemilihan Metode Spin-Off Unit Usaha Sayriah Bank Umum Konvensional Menjadi Bank Umum Syariah di Indonesia. (Disertasi Tidak Dipublikasikan). Jakarta: IEF Trisakti

Rochaety, Ety, dkk. 2007. Meteode Penelitian Bismis: Dangan Aplikasi SPSS. Bandung: Penerbit Mitra Wacana Media.

Sanusia, Anwar. 2013. Metodelogi Penelitian Bisnis. Jakarta: Salemba Empat.

Sholohin, Ahmad Ifham. 2010. Buku Pintar Ekonomi Syariah. Jakarta: Kompas Gramedia.

Simbolon, T.C. 2012. Analisa Perbandingan Kinerja Keuangan Perusahaan Sebelum dan Sesudah Divestasi dan Spin-off. (Tesis Tidak Dipublikasikan). Semarang: Universitas Diponegoro.

Siswantoro, D. 2014. Analysis of Islamic Bank's Performance and Strategy After Spin-off as Islamic Full-fledged Scheme in Indonesia. International Conference on Accounting Studies 2014, ICAS, Kuala Lumpur Malaysia. 
Trisadini, P. \& Abd. Shomad. 2013. Transaksi Bank Syariah. Jakarta: PT. Bumi Aksara.

Tubke, A. 2004. Success Factors of Corporate Spin-Offs. New York: Springer.

Wicaksono, A. 2014. Efisiensi teknis perbankan Indonesia pada bank yang merger-akusisi dan spin off. (skripsi Tidak Dipublikasikan). Jakarta: UIN Syarif Hidayatullah Jakarta. 